\title{
Food and Feeding Habit of Aspidoparia Morar: A Study on Padma River in Northwestern Bangladesh
}

\author{
Md Istiaque Hossain*1, Suraia Sarmin', Md. Mahmudul Alam², Lubna Alam³, Mazlin \\ Mokhtar $^{3}$, M.A. Samad ${ }^{1}$ \\ ${ }^{1}$ Department of Fisheries, University of Rajshahi, Rajshahi, Bangladesh \\ ${ }^{2}$ School of Economics, Finance \& Banking, College of Business, Universiti Utara Malaysia, \\ Kedah, Malaysia \\ 3 Institute for Environment and Development, Universiti Kebangsaan Malaysia, Selangor, \\ Malaysia
}

*corresponding author's email: bitanrubd@yahoo.com

\section{Citation Reference:}

Hossain, M.I., Sarmin, S., Alam, M.M., Alam, L., and Mokhtar, M. 2015. Food and Feeding Habit of Aspidoparia Morar: A Study on Padma River in Northwestern Bangladesh. Trends in Fisheries Research, Vol. 4(1), pp. 24-31. [Online Link]

This is a pre-publication copy.

The published article is copyrighted by the publisher of the journal. 


\title{
Food and Feeding Habit of Aspidoparia Morar: A Study on Padma River in Northwestern Bangladesh
}

\author{
Md Istiaque Hossain ${ }^{* 1}$, Suraia Sarmin¹, Md. Mahmudul Alam², Lubna Alam³, Mazlin Mokhtar³, M.A. \\ Samad $^{1}$ \\ ${ }^{1}$ Department of Fisheries, University of Rajshahi, Rajshahi, Bangladesh \\ ${ }^{2}$ School of Economics, Finance \& Banking, College of Business, Universiti Utara Malaysia, Kedah, Malaysia \\ 3 Institute for Environment and Development, Universiti Kebangsaan Malaysia, Selangor, Malaysia \\ (Email: bitanrubd@yahoo.com)
}

\begin{abstract}
Understanding the interspecific relationships for proper management of an ideal fishery system, food, and feeding habits of fishes are prerequisites. The food and feeding habits including types and amount of feed and seasonal pattern of feeding were studied. 168 Aspidoparia morar were collected from the River Padma, Rajshahi, Bangladesh from May to December, 2011. The relationship between total length and alimentary canal length was tested using OLS regression. Qualitative as well as quantitative analyses of stomach and gut contents of each fish were done by percentage of occurrence and point method and fullness of stomach was measured by fullness index method. Aspidoparia morar was omnivorous due to the presence of both phytoplankton (Chlorophyceae, Euglenophyceae, Bacillariophyceae, Cyanophyceae) and zooplankton (Rotifera, Crustacea) in the gut content. Based on the point method, the average percentage of phytoplankton and zooplankton was $80.71 \%$ and $19.29 \%$, respectively. The highest average percentage of fullness was $72.62 \%$ in October whereas the lowest was $56.55 \%$ in December. The highest average percentage of emptiness recorded was $43.45 \%$ in December and the lowest was $27.38 \%$ in October. Total length was found statistically positively significant $(\mathrm{P}<0.01)$ with the alimentary canal length. Overall, the article concludes that Aspidoparia morar is an omnivore with a higher feeding preference for phytoplankton and the food habits change with the seasons based on the qualitative and quantitative analysis of food.
\end{abstract}

Key words: Food and feeding habit, fullness of stomach, emptiness of stomach, feeding intensity, plankton

\section{Introduction}

Aspidoparia morar is an indigenous small fish that belongs to the cyprinidae family, attaining a maximum length of $17.50 \mathrm{~cm}$ (Chaudhry, 2010), and is widely distributed in Bangladesh, India, Iran, Myanmar, Nepal, Pakistan, and Thailand (Talwar and Jhingran, 1991). It is known as Morari in Bangladesh, Aspidaparie indická in Czech Rep., Aspidoparia in India, Chakale, and Karangi in Nepal (Froese and Pauly, 2012).

Aspidoparia morar is found in streams, rivers, and ponds in plains and mountainous regions. Aspidoparia morar is a major source of animal protein and micronutrients in the diet of rural small-scale farmers (Ross et al., 2003; Hossain et al., 2009). This fish is normally cooked and eaten whole, and its effect on the diet is further enhanced since the bones are rich in calcium (Thilsted et al., 1997). Moreover, Aspidoparia morar is also extensively used as an ornamental fish (Chaudhry, 2010). Formerly abundant in rivers and streams of Bangladesh, Aspidoparia morar populations have seriously declined due to over exploitation augmented by various ecological changes, degradation of the natural habitats, and destructive fishing methods (Chaudhry, 2010; Hossain et al., 2012a).

The knowledge of food and feeding habit helps to select species that produce maximum yield by utilizing all the available potential food of the water bodies without competition (Dewan et al., 1985). The food and feeding habits of fish vary with the time of the day, season, size of fish, various ecological factors, and different food substances present in the water body (Hynes, 1950).

There are only a few studies have been conducted on Aspidoparia morar including reproduction (Breder and Rosen, 1966), first feeding and survival (Malhotra and Munshi, 1985), length-length and length-weightrelationship (Hossain et al., 2009; Hossain, 2010), size at first sexual maturity, condition factor, spawning season, and fecundity (Hossain et al., 2012b). Moreover, no studies have been reported on food and feeding of Aspidoparia morar in Bangladeshi waters. Therefore, this study aims to describe the food and feeding habit of Aspidoparia morar in the Padma River. 


\section{Material and Methods}

This study collected the fish sample of Aspidoparia morar from the Talaimari ghat of Motihar Thana to Bulonpur ghat of Rajpara Thana under the Rajshahi district of the Padma River from May to December 2011. The river is internationally known as the 'Ganges' in the upstream of slow bound Himalayans at 7000 meters above sea level. It enters Bangladesh from India through the Nawabgang district (Latitude $24^{\circ} 50^{\prime} \mathrm{N}$; Longitude $\left.88^{\circ} 26^{\prime} \mathrm{E}\right)$.

The specimens of the selected fish species were collected by fash jal and Jaki jal. The fresh samples were immediately chilled in ice on site and fixed with $10 \%$ buffered formalin upon arrival at the laboratory to prevent further digestion of food materials and to stop the enzymatic activities of the gut contents. In the laboratory, fishes were washed, cleaned and total length and alimentary canal length of each fish was measured in $\mathrm{cm}$ and the fishes were dissected vertically from mouth to anus. Stomach contents were observed and identified under the microscope.

For identification of the food organisms, Ward and Whipple (1959) and Prescott (1962 and 1964) were consulted. The stomach contents were analyzed by the point's method and fullness of stomach was measured using the fullness index method (Hynes, 1950). The stomachs were classified into full, $3 / 4$ full, $1 / 2$ full, $1 / 4$ full and empty. Qualitative and quantitative analysis of food were done using both the point's method and the percentage of frequency of occurrence method.

The number of fish in which each food group occurred was listed as percentage of the total number of fish examined according to the percentage of frequency of occurrence method (Dewan and Saha, 1979). The volume of stomach contents as estimated by observation was recorded on an absolute scale. Points were allotted to each stomach according to the volume of its contents based on the point's method (Hynes, 1950). The stomach with the largest volume was allotted 100 points and each of the stomachs as examined was then rated in one of the following points categories: $0,3,6,12,25,50$ and 100 points, based on the volume of food present. The categories were based on inspection and estimation. However, a set of standards of all the point categories were made from extra stomachs and were needed in relating absolute volumes to assign point values. Stomach with intermediate quantities of food was allotted to the point's category which they most nearly approached.

All the data were subjected to the ANOVA (Analysis of Variance) using the computer software, SPSS (Statistical Package for Social Science). The relationship between total length and alimentary canal length was tested using the OLS regression. Descriptive statistics such as, average percentage and tabular technique, were done to calculate the length weight relationship, types and amount of food, and seasonal pattern of feeding.

\section{Result and Discussion}

\section{Types and amount of food taken by fish}

A variety of food groups were found during the analysis of stomach contents of Aspidoparia morar. A total of 6 groups were identified from the stomach of the fishes examined of which 4 belonged to phytoplankton and 2 belonged to zooplankton (Figure 1). 


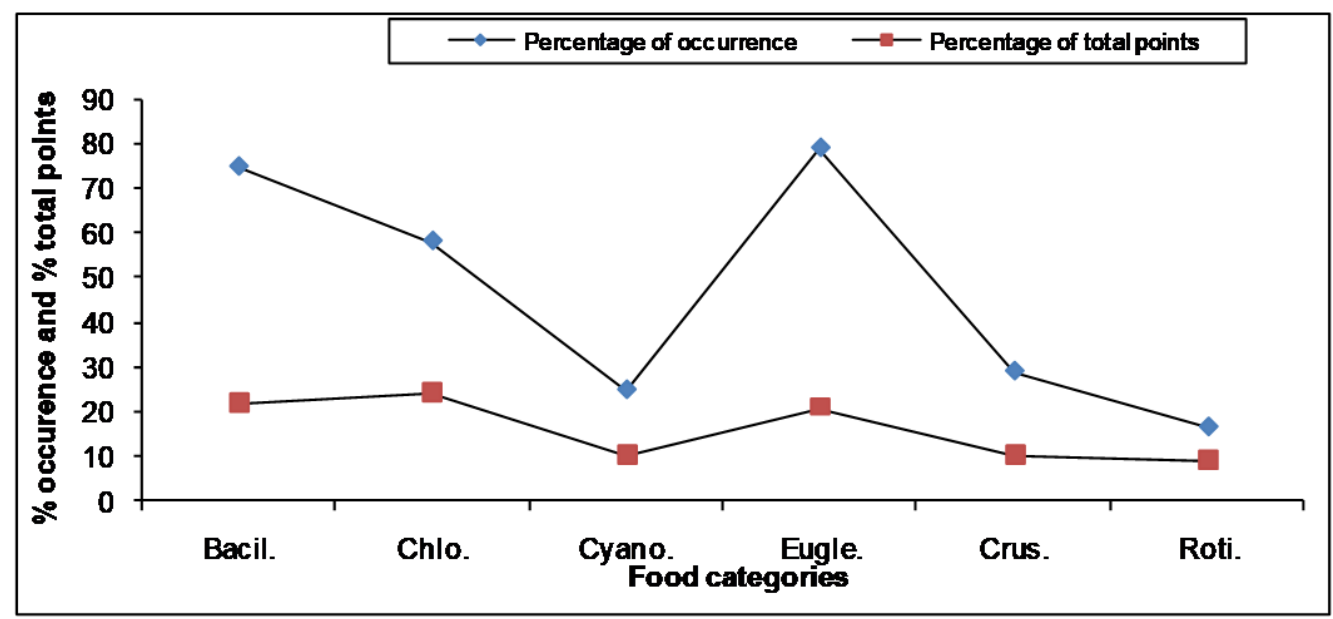

Figure 1: Composition of diet of fish in percentage of occurrence and total points

Among the phytoplankton, Chlorophyceae was the most dominant food group by the percentage of total points $(24.34 \%)$ followed by Euglenophyceae (24.09\%), Bacillareophyceae (21.81\%), Cyanophyceae (10.47\%), Crustacea (10.35\%), and Rotifera (9.09\%) (Table 1).

Table 1: Group status and total points of plankton in gut contents of Aspidoparia morar

\begin{tabular}{lll}
\hline Plankton Type & Food Group & \% total point \\
\hline \multirow{3}{*}{ Phytoplankton } & Bacillariophyceae & 21.81 \\
& Chlorophyceae & 24.34 \\
& Cyanophyceae & 10.47 \\
Zooplankton & Euglenophyceae & 24.09 \\
& Crustacea & 10.35 \\
\hline
\end{tabular}

Shafiqul (2000) studied the food and feeding habit of Dhela (Osteobrama cotio cotio) and reported that by percentage of total points, Chlorophyceae $(60.47 \%)$ and Bacillariophyceae $(17.57 \%)$ were the main food items. The next preferred food items were Cyanophyceae (8.49\%) followed by Euglenophyceae (6.49\%), Crustacea $(4.60 \%)$, Rotifera $(1.67 \%)$, and Benthos $(0.73 \%)$ occupied the successive position. However, not all the food groups were found to occur in all the stomachs of fish with food. For this finding, it can be concluded that the fish Aspidoparia morar is an omnivore in all the size groups of fish. The fish also showed some changes in the patterns of feeding, as they grow big. Hossain et al. (2012) and Keast (1965) reported that many fishes changed diet as they grow. Shafiqur (2003) studied the seasonal variations of food and feeding ecology of a freshwater small fish chela (Chela cachius) in a large reservoir pond in Bangladesh and reported that among phytoplankton, Chlorophyceae was the dominant group followed by Bacillariophyceae and among the zooplankton, rotifera was found more than crustaceans.

\section{Feeding intensity (Fullness and vacuity) of Aspidoparia morar}

Fishes with full, $3 / 4$ full and $1 / 2$ full were considered to feed actively and fishes with $1 / 4$ full were considered to feed poorly and vacuity was considered to feed very poorly or not at a feeding stage. In the month of October, 2011 , total highest fullness of stomach was found to be $72.43 \%$ and total lowest fullness of stomach was found to be $56.55 \%$ in December, 2011. In the month of December, 2011 total highest vacuity of stomach was found to be 43.45 and the total lowest vacuity of stomach was found to be $27.38 \%$ in October (Table 2). From the present study, it can be concluded that the fish changes its food habit with the change of months.

Table 2: Monthly percentage of fullness of stomach of Aspidoparia morar

\begin{tabular}{llllll}
\hline \multirow{2}{*}{ Month , year } & \multicolumn{5}{c}{ Fullness of stomach $(\%)$} \\
\cline { 2 - 6 } & Full & $3 / 4$ full & $1 / 2$ full & $1 / 4$ full & Empty \\
\hline May' 11 & 48 & 42 & 30 & 16 & 32 \\
June' 11 & 40 & 42 & 30 & 39 & 17
\end{tabular}




\begin{tabular}{llllll} 
July' 11 & 42 & 38 & 40 & 16 & 32 \\
Aug' 11 & 46 & 35 & 35 & 22 & 30 \\
Sept' 11 & 48 & 42 & 30 & 16 & 32 \\
Oct' 11 & 50 & 40 & 32 & 16 & 30 \\
Nov' 11 & 30 & 31 & 35 & 30 & 40 \\
Dec' 11 & 20 & 25 & 50 & 24 & 49 \\
\hline
\end{tabular}

Fullness = Full, $3 / 4$ full, $1 / 2$ full, Vacuity $=1 / 4$ full and empty

These findings are more or less similar to those of Dewan and Saha (1979) who reported that Tilapia nilotica changed its food habit with the changes in seasons. Alam et al. (2002) and Dasgupta (1990) stated that the feeding intensity of Tor tor increased with the increase in size. Higher feeding percentage was also recorded among young individuals of Tor putitora. Thomas (1969) stated that low feeding activity might not be due to shortage of food items but due to the spawning season of the fish. Hossain et al. (2012) and Hynes (1950) observed that the fish have adapted to a wide variety of food. Some fishes are herbivorous, carnivorous and omnivorous and also plankton feeders. Variation occurs in the food of fishes throughout the year. Monthly changes in temperature not only influenced food composition and the rate of digestion but also the quantity and quality of various foods.

\section{Occurrence Method}

Bacillariophyceae was found to be the highest at 100\% in the stomach in July and December, 2011 and lowest at $20 \%$ in May, 2011. Chlorophyceae was found to be the highest at $100 \%$ in the stomach in May, June and September 2011 and lowest at 50\% in August, October and December, 2011. Cyanophyceae was found to be the highest at 100\% in the stomach in August, October and November, 2011 and lowest at 35\% in May, 2011. Euglenophyceae was found to be the highest at 60\% in the stomach in December, 2011 and lowest at 30\% in June and October, 2011. Crustacea was found to be the highest at 30\% in the stomach in November, 2011 and lowest at $15 \%$ in September, 2011. Rotifera was found to be the highest at $60 \%$ in the stomach in May, August, October, and November 2011 and lowest at 50\% in June, 2011 (Table 3).

Table 3: Data of the stomach content of Aspidoparia morar analysis by occurrence methods

\begin{tabular}{cccccccc}
\hline Months & $\begin{array}{c}\text { No. of } \\
\text { fish }\end{array}$ & $\begin{array}{c}\text { Bacillariophycea Chlorophycea } \\
\text { e }\end{array}$ & \multicolumn{2}{c}{ e } & \multicolumn{2}{c}{ Cyanopyceae Euglenophyceae Crustacea Rotifera } \\
\hline May, 11 & $\begin{array}{l}\mathrm{N}=21 \\
0=15\end{array}$ & 20 & 100 & 35 & 55 & 20 & 60 \\
June, 11 & $\begin{array}{l}\mathrm{N}=21 \\
\mathrm{O}=15\end{array}$ & 60 & 100 & 60 & 30 & 20 & 50 \\
July, 11 & $\begin{array}{l}\mathrm{N}=21 \\
\mathrm{O}=15\end{array}$ & 100 & 60 & 60 & 31 & 25 & 55 \\
Aug, 11 & $\begin{array}{l}\mathrm{N}=21 \\
\mathrm{O}=15\end{array}$ & 50 & 50 & 100 & 35 & 20 & 60 \\
Sept, 11 & $\begin{array}{l}\mathrm{N}=21 \\
\mathrm{O}=15\end{array}$ & 55 & 100 & 50 & 35 & 15 & 55 \\
Oct, 11 & $\begin{array}{l}\mathrm{N}=21 \\
\mathrm{O}=15\end{array}$ & 60 & 50 & 100 & 30 & 25 & 60 \\
Nov, 11 & $\begin{array}{l}\mathrm{N}=21 \\
\mathrm{O}=15\end{array}$ & 50 & 55 & 100 & 50 & 30 & 60 \\
$\mathrm{~N}=21$ & 100 & 50 & 40 & 60 & 20 & 55 \\
\hline
\end{tabular}

( $\mathrm{N}=$ Number of fish examined, $\mathrm{O}=$ Number of fish with food)

\section{Point's method}

The stomach contents of Aspidoparia morar consisted of six broad groups namely Bacillariophyceae, Chlorophyceae, Cyanopyceae, Euglenophyceae, Crustacea, and Rotifera and variations of these food items were consumed during different months of the study period. The average number of Bacillariophyceae was $21.81 \%$ of the stomach contents during the research period. During this period, maximum number of $22.72 \%$ was recorded in October, 2011 and the minimum of $20.63 \%$ in August, 2011. The average number of Chlorophyceae was 
$24.34 \%$ of the stomach contents. The maximum number of $25.55 \%$ was recorded in May, 2011 and the minimum of $23.12 \%$ in November, 2011. The average number of Cyanopyceae was $10.47 \%$ of the stomach contents. The maximum number of $11.09 \%$ was recorded in November, 2011 and the minimum of $9.54 \%$ in July, 2011. The average number of Euglenophyceae was $24.09 \%$ of the stomach contents. The maximum number of $25.49 \%$ was recorded in September, 2011 and the minimum of $23.32 \%$ in July, 2011. The average number of Crustacea was $10.35 \%$ of the stomach contents. The maximum number of $11.43 \%$ was recorded in July, 2011 and the minimum of $9.63 \%$ in September, 2011. The average number of Rotifera was $9.09 \%$ of the stomach contents. The maximum number of $9.63 \%$ was recorded in September, 2011 and the minimum of $8.30 \%$ in July, 2011 (Table 4).

Table 4: Percentage of total points of different food categories by point's method

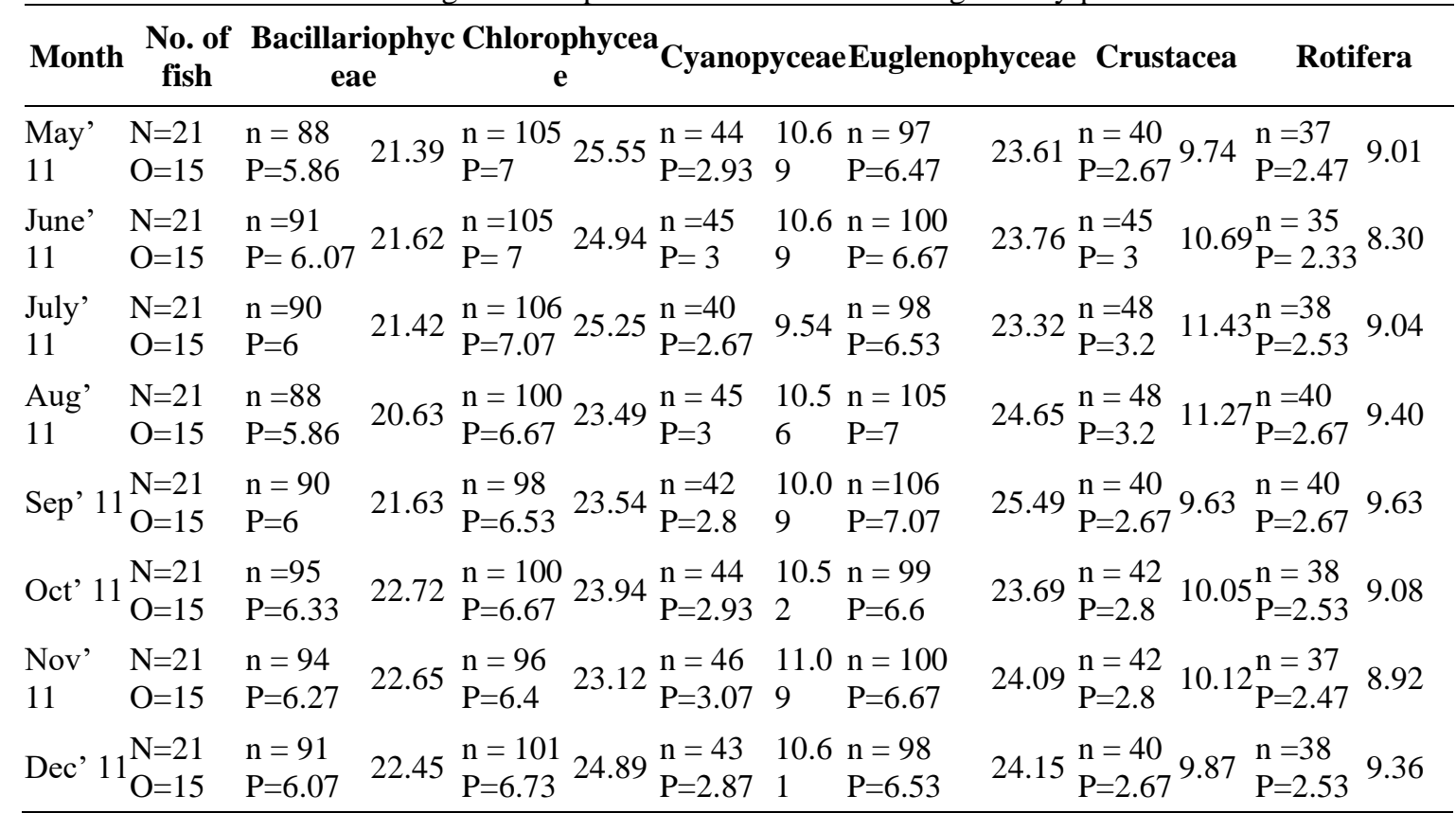

$\mathrm{N}=$ Number of fish examined, $\mathrm{O}=$ Number of fish with food, $\mathrm{P}=$ Number of points per fish, $\mathrm{n}=$ Number of food category found

\section{Relationship between total length (TL) and alimentary canal length (ACL)}

Mathematical relationship between total length (TL) and alimentary canal length (ACL) was established from the observed data and the values of regressions, correlation-efficient, point of intercepts, and standard deviation were computed (Table 5) using the statistical formula according to Simpson (1951). The results showed that total length was positive and significant $(\mathrm{P}<0.01)$ with the alimentary canal length.

Table 5. Relation between total length and alimentary canal length (ACL) of Aspidoparia morar

\begin{tabular}{|c|c|c|c|c|c|c|}
\hline \multirow{2}{*}{$\begin{array}{l}\text { Months, } \\
\text { Year }\end{array}$} & Total length & $\begin{array}{l}\text { Alimentary } \\
\text { canal length }\end{array}$ & $\begin{array}{l}\text { Value of } \\
\text { intercepts }\end{array}$ & $\begin{array}{c}\text { Regression co- } \\
\text { efficient }\end{array}$ & $\begin{array}{c}\text { Co-efficient of } \\
\text { correlation }\end{array}$ & \multirow{2}{*}{$\begin{array}{c}\begin{array}{c}\text { Level of } \\
\text { significance }\end{array} \\
\mathrm{P}<0.01\end{array}$} \\
\hline & $\begin{array}{c}\text { Mean } \pm \text { SD } \\
\text { ' } x \text { ' }\end{array}$ & $\begin{array}{c}\text { Mean } \pm \text { SD } \\
\text { 'y' }\end{array}$ & Value of 'a' & Value of 'b' & Value of 'r' & \\
\hline May’ 11 & $10.21 \pm 1.80$ & $11.55 \pm 1.63$ & 2.7606 & 0.8603 & $0.946 * *$ & $\mathrm{P}<0.01$ \\
\hline June' 11 & $10.02 \pm 2.39$ & $11.28 \pm 2.54$ & 0.8526 & 1.0404 & $0.981 * *$ & $\mathrm{P}<0.01$ \\
\hline July’ 11 & $8.91 \pm 1.40$ & $10.43 \pm 1.53$ & 1.112 & 1.0451 & $0.960 * *$ & $\mathrm{P}<0.01$ \\
\hline Aug' 11 & $9.44 \pm 2.11$ & $10.95 \pm 2.15$ & 1.5221 & 0.9987 & $0.983 * *$ & $\mathrm{P}<0.01$ \\
\hline Sep' 11 & $10.02 \pm 2.39$ & $11.28 \pm 2.54$ & 0.8526 & 1.0404 & $0.981 * *$ & $\mathrm{P}<0.01$ \\
\hline Oct' 11 & $10.21 \pm 1.80$ & $11.55 \pm 1.63$ & 2.7606 & 0.8603 & $0.946 * *$ & $\mathrm{P}<0.01$ \\
\hline
\end{tabular}




\begin{tabular}{lllllll}
\hline Nov' 11 & $8.91 \pm 1.40$ & $10.43 \pm 1.53$ & 1.112 & 1.0451 & $0.960 * *$ & $\mathrm{P}<0.01$ \\
Dec' 11 & $9.20 \pm 1.19$ & $10.39 \pm 1.32$ & 1.3091 & 0.9866 & $0.888 * *$ & $\mathrm{P}<0.01$ \\
\hline
\end{tabular}

' $a$ ' refers as the values of intercepts, 'b' refers regression co-efficient, and 'r' refers co-efficient of correlation

\section{Conclusion}

Based on the qualitative and quantitative analysis of food of the fish, it can be concluded that, Aspidoparia morar is an omnivore with a higher feeding preference for phytoplankton. The feeding activity of the fish was found to vary with total length (TL) and alimentary canal length (ACL). Aspidoparia morar was found to change its feeding activity with the change in season and they were more active during winter compared to summer. The fish showed two feeding peaks; the major one was in winter and the minor one was in late summer. It was found to change its food habits with the change in seasons.

\section{Acknowledgement}

We are thankful to the research grants GGPM-2014-010 and LRGS 203/PKT/6720004 (Programme 203/PKT/6724003).

\section{References}

Alam MA, Dewan S, Hossain MI, Hussain MG. (2002) Food and feeding habit of Tor putitora (Hamilton). Univ.j.zool. Rajshahi Univ, 21, 21-22.

Baeck GW, Park C, Choi HC, Huh SH, Park JM. (2011). Feeding habits of ocellate spot skate, Okamejei kenojei (Mu“ ller \& Henle, 1841), in coastal waters of Taean, Korea. Journal of Applied Ichthyology. 27, 10791085 .

Bhuiyan AS, Afroz S, Zaman T. (2006). Food and feeding habit of the juvenile and adult snakehead, Channa Punctatus (bloch). Journal of Life Earth Science, 1(2). 53-54.

Breder CM, Rosen DE. (1966). Modes of reproduction in fishes. T.F.H. Publications, Neptune City, New Jersey. Chaudhry S. (2010). Cabdio morar. In: IUCN (2012). IUCN Red List of Threatened Species. Version 2012.2. <www.iucnredlist.org>. Downloaded on 19 November 2012.

Coad BW (1981). Fishes of Afghanistan, an annotated check-lish. Publ. Zool. Natl. Mus. Can. 14, 23p.

Dasgupta M (1990). A study on the food and feeding habits of the mahseer Tor tor (Hamilton). Indian Journal of Fiseries, 37(4), 297-304.

Dewan S and Saha SN. (1979) Food and feeding habits of Tilapia nilotica (L.) (Perciformes: Cichlidae). II. Diel and Seasonal patterns of feeding. Bangladesh Journal of Zoology, 7(2), 75-80.

Dewan S, Ali MM, Islam AM. (1977). Studies on the size and patterns of feeding of fries and fingerlings of three major carps viz., Labeo rohita (Ham.), Catla catla (Ham.) and Cirrhina mrigala (Ham.). Bangladesh Journal of Agriculture, 2(2), 223-238.

Dewan S, Ali MM, Islam MA. 1997. Studies on the size and patterns of feeding of fries patterns of feeding of fries and fingerlings of the major carps, viz. Labeo rohita (Ham.), Catla catla (Ham.) and Cirrhina mrigala (Ham.) Bangladesh Journal of Agriculture, 2(2), 223-228.

Dewan S, Miah MJU, Mazumdar K. (1985). Bangladesh Journal of Aquaculture, 6-7, 39-44.

Dewan S, Miah MJU, Uddin MM. (1983). Studies on the food and feeding habits of Cyprinus carpio (Lin.) I, types and amount of food taken by the fish and its size and patterns of feeding. Bangladesh. Journal of Aquaculture,2-5(1), 83-89.

Dewan S, Miah MJU, Uddin MN. (1985). Studies on the food and feeding habits of Cypirnus carpio. II. Diel and seasonal patterns of feeding of the fish. Bangladesh. Journal of Aquaculture, 6-7(1),11-18.

Froese R, Pauly D. (Eds) (2012). FishBase 2012. World Wide Web electronic publication. Available at: http://www.fishbase.org (accessed on 19 November 2012).

Hossain MI, Nipa FR, Tumpa AS, Mannan MA and. Bhuyain MAB. (2012). Food and Feeding Habit of Puntius Sarana in The River of Padma, Rajshahi, Bangladesh. Trends in Fisheries Research, 1 (3), 2319-4758.

Hossain MY, Arefin MS, Mohmud MS, Hossain MI, Jewel MAS, Rahman MM, Ahamed F, Ahmed ZF Ohtomi J. (2012b). Length-weight relationships, condition factor, gonadosomatic index-based size at first sexual maturity, spawning season and fecundity of Aspidoparia morar (Cyprinidae) in the Jamuna River (Brahmaputra River distributary), northern Bangladesh. Journal of Applied Ichthyology. doi: 10.1111/jai.12127. in press.

Hossain MY, Jasmine S, Ibrahim AHM, Ahmed ZF, Rahman MM, Ohtomi J. (2009). Length-weight and length-length relationships of 10 small fish species from the Ganges, Bangladesh. 25, 117-119. 
Hossain MY, Rahman MM, Fulanda B, Jewel MAS, Ahamed F, Ohtomi J. (2012a): Length-weight and lengthlength relationships of five threatened fish species from the Jamuna (Brahmaputra River tributary) River, northern Bangladesh. J. Appl. Ichthyol. 28, 275-277.

Hossain MY. (2010). Morphometric Relationships of Length-Weight and Length-Length of Four Cyprinid Small Indigenous Fish Species from the Padma River (NW Bangladesh). Turkish Journal of Fisheries and Aquatic Sciences, 10, 131-134.

Hynes HBN. (1950). The food of freshwater stacle backs Gasterosteus aculeatus and Pygesteus pungitus, with a review of methods used in studies of the food of fishes. Journal of Animal Ecology, 19, 36-58.

Keast A (1965). Resource subdivisions among cohabiting fish species in a bay, Lake Opinicon, Ontario. Proc. Eight Conf. Great Lake Res. Div., Univ. Michigan. 106-132.

Lashari PK, Narejo NT, Laghari MY. (2010). Feeding Behavior of a Carp, Cirrhinus reba (Hamilton) from Fishponds of District Jacobabad, Sindh, Pakistan. Pakistan Journal of Zooogy, 42(3), 345-348.

Malhotra YR, Munshi S. (1985). First Feeding and Survival of Aspidoparia morar Larvae (Cyprinidae). Transactions of the American Fisheries Society. 114(2), 286-290.

Menon AGK. (1999). Check list - fresh water fishes of India. Rec. Zool. Surv. India, Misc. Publ., Occas. Pap. No. 175,366 pp.

Oso JA, Ayodele A, Fagbuaro O. (2006). Food and Feeding Habits of Oreochromis niloticus (L.) and Sarotherodon galilaeus (L.) in a Tropical Reservoir. World Journal of Zoology, 1 (2), 118-121.

Parveen S (1984) Studies on culture Methods and some aspects of the biology of A. Mola. M. Sc. Thesis Dept. of Zool. Univ. Dhaka. 115pp.

Pillay TVR. (1952). A critique of the methods of study of food of fishes. J. Zoological Society of India, 1, 185200.

Rahman MM, Hossain MY, Ahamed F, Fatematuzzhura, Subba BR, Abdallah EM, Ohtomi J. (2012). Biodiversity in the Padma distributary of the Ganges River, Northwestern Bangladesh: recommendations for conservation. World Journal of Zoology. 6634-WJZ. (in press).

Rahmatullah SM, Nurrunnabi SM and Islam MA (1997). Studies on the food and feeding habits and electivity indices of young freshwater Cyprinid, mola, Amblypharygodon mola. Bangladesh Journal of Agricultural Science, 24(2), 81-86.

Ross N, Islam M, Thilsted SH. (2003). Small indigenous fish species in Bangladesh: contribution to vitamin A, calcium and iron intakes. Journal of Nutrition, 133, 4021-4026.

Shafiqul MI. (2000). Food and feeding habit and fecundity of Dhela Osteobrama cotio cotio (Ham.) M.Sc. Thesis, Department of Fisheries Management, Bangladesh Agricultural University, Mymensingh.

Shafiqur MR (2003). Seasonal variation of food and feeding ecology of a freshwater small fish Chela (Chela cachius) in a large reservoir pond in Bangladesh.

Simpson AC (1951). The fecundity of the plaice. Fish Invesi. London. Sec. 2 (17), 1-27.

Talwar PK, Jhingran AG. (1991). Inland fishes of India and adjacent countries. vol 1. A.A. Balkema, Rotterdam. 541 pp.

Thilsted SH, Roos N, Hasan N. (1997). The role of small indigenous fish species in food and nutrition security in Bangladesh. NAGA Newsletter, July-Dec.13 pp.

Thomas PA (1969). Goat fishes (Fam. Mullidae) of the Indian seas. Marine. Biological Association. India Memoir.III.7, 152-157.

Ward, H.B. and G.C. Whipple. 1954. Fresh water Biology. 2nd ed. John Willey and sons. Inc., New York. 1248 pp. 